\title{
Louisiana: Two-Party Growth and Increasing Party Polarization
}

\author{
Robert E. Hogan
}

This paper examines party organizations in Louisiana from the perspective of those at the grassroots. An assessment of local organizations as well as the attitudes of the party activists themselves shows that politics in this state are in a period of transition. Over the past decade, Republicans have continued to make significant electoral gains; however, the major changes have occurred within the Democratic Party. The demographic transformation of Democratic activists and their corresponding support for more liberal policy positions contributes to an increasingly polarized party system in the state.

\section{Introduction}

Louisiana has undergone extensive political change over the past three decades. While Republican gains have been less dramatic here than in other southern states, the slow movement toward two-party competition has altered the political landscape nonetheless. This article examines some of these changes as reflected in the issue positions, ideology, and attitudes of Democratic and Republican Parish Executive Committees members. An examination of those on the front-line of party efforts of recruitment, issue development, and electioneering provides a glimpse of recent changes in party development in this formerly one-party state. The findings have implications for understanding the role of parties in elections and for our theories concerning party development and change.

This look at grassroots activists in Louisiana demonstrates that parties in the state have become more distinct and polarized over time. For example, on matters of ideology and issue positions, the Republican and Democratic activists are clearly less alike than they were 10 years ago. Such changes at the grassroots of party politics suggest that Louisiana continues to be in a period of political transition.

\section{Development of Political Parties in Louisiana}

The Republican Party in Louisiana has grown substantially over the past three decades, but unlike in other southern states, the party's success has been uneven. Republicans have done well in capturing the governor's

ROBERT E. HOGAN is assistant professor of political science at Louisiana State University in Baton Rouge. The author wishes to thank the following former LSU students for their assistance during various stages of the project: Derrick Banks, Jessica Downey, and Trevor Williams.

The American Review of Politics, Vol. 24, Spring, 2003: 53-68

(C)2003 The American Review of Politics 
mansion and a majority of the seats to the U.S. House, yet Louisiana Democrats continue to hold both U.S. Senate seats and large majorities in the state legislature. A brief review of changing electoral fortunes and organizational developments of the parties provides a context in which to understand party activists' attitudes and behavior.

\section{Electoral Changes}

As has occurred throughout the southern region, Republicans have made significant electoral gains in the state since 1960. Table 1 displays the vote percentages received by Republicans running for President, Governor, and U.S. Senator in addition to the delegation percentages in the U.S. House, State Senate, and State House. In interpreting these results, it is important to understand the unique open elections system that Louisiana has used since 1975. Under this system, all candidates (both Republican and Democrat) first compete against one another in an initial round of elections. If no candidate receives a majority of the vote, the top two vote getters must compete in a second round of elections. In such a run-off, two Democrats or two Republicans may end up competing against one another. Such a system of elections is often viewed as beneficial to incumbent candidates, particularly in legislative races (Parent and Perry 1998).

As one can see from Table 1, Republican candidates have been more successful in winning some offices than others. In the last 11 presidential elections, Louisiana voters have gone with the Republican nominee six times, with the highest percentage of the vote going to Richard Nixon in 1972 (66 percent). Of the last eleven gubernatorial elections, Republican candidates have won only 3 times; however, the last two elections were won by large margins. Republican Mike Foster's 1999 gubernatorial re-election did not even require a run-off and he won with 62.2 percent. In contests for the U.S. Senate, Democrats continue to dominate, although Democrat Mary Landrieu's 1996 and 2002 winning margins were thin. Among Louisiana's U.S. House delegation, the GOP has found greater success. Not until 1972 was the first Republican elected since Reconstruction, but by the late 1990s the party held 5 of the state's 7 congressional seats. In state legislative elections, Republicans have made significant gains, but they clearly remain the minority party. It was not until 1986 that Republicans held more than 10 percent of the seats in either chamber. By 2002, Republicans still held only about a third of the statehouse seats.

Overall, Republicans continue to make inroads in statewide elections, where they are clearly competitive with the Democrats. Below the state level, however, Republicans do well in congressional races, but Democrats still have firm control of the state legislature. 
Table 1. Republican Strength in Louisiana, 1960-2002*

\begin{tabular}{|c|c|c|c|c|c|c|}
\hline Year & $\begin{array}{c}\text { Percent of } \\
\text { Presidential } \\
\text { Vote }\end{array}$ & $\begin{array}{c}\text { Percent of } \\
\text { U.S. Senate } \\
\text { Vote }\end{array}$ & $\begin{array}{c}\text { Percent of } \\
\text { Gubernatorial } \\
\text { Vote }\end{array}$ & $\begin{array}{l}\text { Percent of } \\
\text { U.S. House } \\
\text { Delegation }\end{array}$ & $\begin{array}{l}\text { Percent of } \\
\text { State House } \\
\text { Delegation }\end{array}$ & $\begin{array}{r}\text { Percent of } \\
\text { State Senate } \\
\text { Delegation }\end{array}$ \\
\hline 1960 & 28.6 & 20.2 & 17.0 & 0.0 & 0.0 & 0.0 \\
\hline 1962 & & 24.4 & & 0.0 & 0.0 & 0.0 \\
\hline 1964 & 56.8 & & 38.5 & 0.0 & 0.0 & 1.9 \\
\hline 1966 & & 0.0 & & 0.0 & 0.0 & 1.9 \\
\hline 1968 & 23.5 & 0.0 & 0.0 & 0.0 & 0.0 & 0.0 \\
\hline 1970 & & & & 0.0 & 2.6 & 1.0 \\
\hline 1972 & 66.0 & 19.1 & 42.8 & 12.5 & 2.6 & 3.8 \\
\hline 1974 & & 0.0 & & 25.0 & 2.6 & 3.8 \\
\hline 1976 & 46.0 & & 0.0 & 25.0 & 2.6 & 3.8 \\
\hline 1978 & & 0.0 & & 37.5 & 0.0 & 8.6 \\
\hline 1980 & 51.2 & 0.0 & 50.3 & 25.0 & 0.0 & 9.5 \\
\hline 1982 & & & & 25.0 & 2.6 & 10.5 \\
\hline 1984 & 60.8 & 9.0 & 36.3 & 25.0 & 2.6 & 10.5 \\
\hline 1986 & & 47.2 & & 37.5 & 12.8 & 14.3 \\
\hline 1988 & 54.3 & & 18.6 & 50.0 & 12.8 & 16.2 \\
\hline 1990 & & 43.5 & & 50.0 & 15.4 & 16.2 \\
\hline 1992 & 41.0 & 8.0 & 38.8 & 42.9 & 15.4 & 15.2 \\
\hline 1994 & & & & 42.9 & 15.8 & 15.2 \\
\hline 1996 & 40.4 & 49.8 & 63.5 & 42.9 & 33.8 & 26.6 \\
\hline 1998 & & 31.6 & & 71.4 & 35.9 & 25.7 \\
\hline 2000 & 52.6 & & 62.2 & 71.4 & 33.3 & 29.5 \\
\hline 2002 & & 48.3 & & 57.1 & 33.3 & 32.4 \\
\hline
\end{tabular}

Another aspect of the political context that may give insight into the changing political climate is party registration of the state's voters. While registration figures often lag real changes in voter preferences, they can serve as an indicator of shifting party fortunes over time. Table 2 displays the registration percentages for white and black voters from 1980 to 2002. Looking first at the "total" column we find a decreasing percentage of voters registered as Democrats and an increasing percentage registered as Republicans or as "other" (unaffiliated and minor parties). Democrats constituted nearly 87 percent of registered voters in 1980 , but by 2002 that percentage had dipped to less than 58 percent. It is interesting to note that the size of the decrease in registered Democrats is much larger than the increase in the percentage of Republican registrants, meaning that movement has been toward the unaffiliated or minor party category. Whereas the "other" category 
constituted only 6 percent of registered voters in 1980, by 2002 this percentage had increased to over 19 percent.

Examining these percentages by racial category shows that the movement of registrants has not been similar for all groups. Specifically, the largest movement has occurred among white voters to the Republican Party. Whereas 84 percent of white voters were registered as Democrats in 1980, by 2002 that percentage had dropped to less than 49 percent. Only 9 percent of whites were registered as Republicans in 1980, but by 2002, nearly onethird of whites were registered Republicans. Over this same time frame, smaller percentages of blacks were also registered as Democrats. However, the movement of blacks was not so much toward Republican registration as it was to the "other" category (less than 4 percent of blacks were registered as "other" in 1980, but by 2002 the percentage was nearly 15 percent).

Table 2. Louisiana Voter Registration by Race, 1980-2002

\begin{tabular}{|c|c|c|c|c|c|c|c|c|c|}
\hline \multirow[b]{2}{*}{ Year } & \multicolumn{3}{|c|}{ - Percent of Total_- } & \multicolumn{3}{|c|}{-Percent of Whites - } & \multicolumn{3}{|c|}{-Percent of Blacks- } \\
\hline & Dem & Rep & Other & Dem & Rep & Other & Dem & Rep & Other \\
\hline 1980 & 86.6 & 7.4 & 6.0 & 84.2 & 9.0 & 6.7 & 94.3 & 2.1 & 3.6 \\
\hline 1981 & 86.1 & 7.8 & 6.1 & 83.7 & 9.5 & 6.8 & 94.1 & 2.2 & 3.7 \\
\hline 1982 & 85.2 & 8.3 & 6.5 & 82.5 & 10.2 & 7.2 & 93.4 & 2.4 & 4.2 \\
\hline 1983 & 83.5 & 9.1 & 7.4 & 80.3 & 11.3 & 8.4 & 93.0 & 2.6 & 4.4 \\
\hline 1984 & 81.6 & 10.5 & 7.9 & 77.8 & 13.1 & 9.0 & 93.0 & 2.5 & 4.5 \\
\hline 1985 & 79.7 & 12.4 & 7.9 & 75.2 & 15.7 & 9.1 & 92.9 & 2.6 & 4.5 \\
\hline 1986 & 78.2 & 13.5 & 8.3 & 73.4 & 17.2 & 9.4 & 92.2 & 2.7 & 5.0 \\
\hline 1987 & 77.4 & 14.0 & 8.6 & 72.4 & 17.8 & 9.8 & 92.1 & 2.8 & 5.1 \\
\hline 1988 & 75.1 & 16.4 & 8.4 & 69.3 & 21.2 & 9.5 & 91.9 & 3.0 & 5.1 \\
\hline 1989 & 74.8 & 17.2 & 8.0 & 68.8 & 22.2 & 9.1 & 92.0 & 3.0 & 4.9 \\
\hline 1990 & 74.0 & 17.8 & 8.2 & 67.7 & 23.0 & 9.2 & 91.7 & 3.3 & 5.1 \\
\hline 1991 & 73.3 & 18.1 & 8.5 & 66.7 & 23.7 & 9.6 & 91.3 & 3.3 & 5.3 \\
\hline 1992 & 71.9 & 18.8 & 9.3 & 64.8 & 24.8 & 10.5 & 90.8 & 3.4 & 5.8 \\
\hline 1993 & 71.1 & 19.2 & 9.7 & 63.8 & 25.2 & 10.9 & 90.5 & 3.4 & 6.1 \\
\hline 1994 & 70.6 & 19.4 & 10.0 & 63.3 & 25.5 & 11.2 & 90.2 & 3.4 & 6.4 \\
\hline 1995 & 68.4 & 20.0 & 11.6 & 61.0 & 26.6 & 12.4 & 88.2 & 3.5 & 8.3 \\
\hline 1996 & 65.4 & 21.0 & 13.6 & 57.7 & 28.2 & 14.1 & 86.2 & 3.6 & 10.2 \\
\hline 1997 & 63.9 & 21.3 & 14.8 & 56.0 & 28.8 & 15.2 & 85.3 & 3.6 & 11.1 \\
\hline 1998 & 62.5 & 21.5 & 16.0 & 54.7 & 29.1 & 16.2 & 84.5 & 3.6 & 12.0 \\
\hline 1999 & 61.4 & 21.6 & 17.0 & 53.4 & 29.3 & 17.3 & 83.7 & 3.5 & 12.7 \\
\hline 2000 & 60.1 & 22.0 & 17.9 & 51.8 & 29.9 & 18.2 & 82.9 & 3.5 & 13.5 \\
\hline 2001 & 58.9 & 22.7 & 18.4 & 50.2 & 31.1 & 18.7 & 82.5 & 3.5 & 14.0 \\
\hline 2002 & 57.6 & 23.1 & 19.3 & 48.7 & 31.7 & 19.6 & 81.6 & 3.5 & 14.9 \\
\hline
\end{tabular}


While party registration is merely one indicator of partisan affiliation, these differences over time portend important changes in the party's coalition of support. Whereas blacks comprised only 25 percent of Democratic registered voters in 1980, by 2001 that percentage had increased to over 41 percent. Such changes mean that the success of Democrats at the state level increasingly hinges on their ability to mobilize black voters. This also means that the Democratic Party itself represents a more racially diverse set of voters and this may have important implications for party activities at the grassroots.

\section{Organizational Attributes}

Organizationally the state parties in Louisiana have changed in very minor ways over the past decade. Regarding levels of staffing and other organizational attributes, both parties at the state level resemble the descriptions that were made of them in the early 1990s (Hadley and Horan 1995; Parent 1997). Politics in Louisiana revolve around the personalities of elected officials, and party organizations continue to search for their niche in the electoral process. Republicans have probably made more advances than Democrats have, especially in their use of programmatic activities at the grassroots level. A recent voter "re-registration" drive aimed at switching the party registration of many long-time Democratic voters is one such example. But probably the most prominent change over the last decade involves the growing importance of legislative party committees for purposes of fundraising. Given the campaign finance restrictions adopted in the late 1980s, the role of parties in funneling money to candidates has taken on added significance and will continue to do so in the foreseeable future.

A very visible aspect of party activity in Louisiana involves the continual infighting among various factions within the Republican Party. The on-going disagreement between religious conservatives and mainstream members of the party that began in the late 1980s dogged the party through the better part of the 1990s. Controversies erupted over a number of issues, especially those involving control of the state's Central Executive Committee. In 1998, the legislature passed and the governor signed a bill to expand the membership of the Republican Party's Central Committee to include several elected Republican leaders. This attempt to include more mainstream elements of the party was met with opposition by those on the religious right who took the battle to court. A judge ultimately diffused the situation by throwing out the proposed change. This is merely one example in a series of squabbles within the Republican Party ranging from disputes over presidential caucuses, to problems of staffing at the party headquarters. On most of these issues the fault line centered on the split between traditionalist Republicans and those on the religious right. 
Democrats have certainly not been immune from this sort of internal strife, however, controversies for Democrats have manifested themselves less in the party apparatus than in the various candidate coalitions that form during elections. Previous studies indicate the circumstances under which "feuds" have developed, such as the one between now U.S. Senator Mary Landrieu and State Senator Cleo Fields during their bids for governor in 1995 (Renwick et al. 1999). Wounds from such disputes run deep within the Democratic Party and have had serious consequences for the party's ability to win elections. But then again, such disputes seem mild compared to the problems Republicans faced during the candidacies of David Duke in the early 1990s (Kuzenski et al. 1995; Rose 1992).

\section{Grassroots Party Activists, 2001 and 1991}

Having discussed the changing electoral fortunes of the parties and the altered Democratic and Republican coalitions within the state, we now examine the attitudes and activities of those who work in the parties. Given that the 1991 data have been analyzed extensively elsewhere (Hadley and Horan 1995), the present analysis focuses on the 2001 data with a mention of patterns that vary from those uncovered in the earlier period.

\section{Who Are the Activists?}

Table 3 displays the characteristics of Democrat and Republican activists on several demographic and attitudinal dimensions. As one can see, activists of both parties share a number of common characteristics. A majority of activists in each party are white men over the age of 50 who grew up in Louisiana. In addition, a majority from each party holds at least a college degree and has a family income in excess of $\$ 50,000$. As a group these activists are clearly different from the state population as a whole, but significant differences between the parties are also present. Compared to Democrats, Republican activists tend to be younger, less racially diverse, more Protestant, higher income, and more likely to have grown up outside of Louisiana. Women comprise a larger percentage of the Democratic activists.

One of the largest differences between the parties is in the racial makeup of the activists. Whereas blacks comprise nearly 30 percent of the membership within the Democratic Party, only about 3 percent of the Republican membership is black. Compared to a decade ago, we see blacks constituting an increasingly larger percentage of the Democratic membership. This change is partly a reflection of the growing proportion of blacks within the coalition of registered Democratic voters as indicated earlier. 
Table 3. Characteristics of Louisiana Party Activists

\begin{tabular}{|c|c|c|c|}
\hline Characteristics & & Democrats & Republicans \\
\hline \multirow[t]{3}{*}{ Age } & Percent Under 40 & 15.5 & 21.2 \\
\hline & Percent Over 50 & 62.9 & 55.9 \\
\hline & Percent Over 65 & 22.3 & 19.9 \\
\hline Gender & Percent Women & 34.1 & 26.9 \\
\hline \multirow[t]{3}{*}{ Race / Ethnicity } & White & 66.9 & 94.7 \\
\hline & Black & 29.6 & 2.9 \\
\hline & Other & 3.5 & 2.4 \\
\hline Lived Early Years & Percent in Louisiana & 88.7 & 75.3 \\
\hline \multirow[t]{2}{*}{ Education } & High School or less & 15.6 & 7.0 \\
\hline & College Degree or higher & 55.5 & 65.3 \\
\hline \multirow[t]{2}{*}{ Family Income } & Over $\$ 50,000$ & 66.7 & 76.9 \\
\hline & Over $\$ 100,000$ & 21.0 & 32.9 \\
\hline \multirow[t]{3}{*}{ Religion } & Protestant & 45.7 & 54.1 \\
\hline & Catholic & 50.4 & 41.0 \\
\hline & Other / None & 3.9 & 4.9 \\
\hline Attend Church & At least once a week & 54.3 & 51.9 \\
\hline Religion in Life & Very important & 55.3 & 51.7 \\
\hline Born Again Christian & Percent Reporting & 41.2 & 37.1 \\
\hline Religious Right & Close or Very Close & 23.0 & 33.8 \\
\hline
\end{tabular}

Given the prominent role of religion in state politics, comparisons of the parties on this dimension are also displayed in Table 3. Catholics comprise a high percentage of the state's population so it is not particularly surprising that so many activists are also Catholic. Over 50 percent of Democratic activists are Catholic, compared to 41 percent of Republican activists. Over the past decade, the percentage of Catholics has increased in both parties, but particularly in the Republican Party where the percentage increased by about 10 points (a change from 31 to 41 percent). The larger increase among Republican activists may reflect the prominence of the abortion issue over the past decade. It may also be a result of the inroads made by Republicans in traditionally Democratic parishes in the southern, more Catholic portions of the state.

Other religious dimensions are also provided in Table 3, although not all show large differences between the parties. Similarly higher percentages of activists attend church on a weekly basis and feel that religion plays a 
large role in their lives. As one might expect, a greater proportion of Republicans than Democrats say that they feel close the Religious Right (34 percent compared to 23 percent). But, interestingly, a higher percentage of Democratic than Republican activists report being "born again Christians" (41 percent to 37 percent). The similarity of responses from activists of both parties regarding religion demonstrates that these attitudes and beliefs are not a major source of inter-party cleavage.

\section{Ideology, Issue Positions, and Partisanship}

Now that we have information on the characteristics of these party activists, we need to know more about their general attitudes and beliefs. Writing about Louisiana parties in 1991, Hadley and Horan (1995) concluded that activists in both parties "should be characterized by degrees of conservatism rather than polarized extremes" (p. 162). The major question to address now is whether this continues to be a fair assessment of activists in the state.

Table 4 provides responses to questions about ideology and specific issue positions. As one might expect, Democrats are more likely to say they are "liberal" while Republicans are more likely to label their personal ideology as "conservative." However, Republicans are twice as likely to call themselves conservative as Democrats are to call themselves liberal. At the same time, over three times as many Democrats as Republicans say they are "middle of the road." Such ideological differences between the parties are large and there is evidence that they have increased over time. For example, in 1991 only 28 percent of Democrats said that they were "somewhat liberal" or "very liberal," but by 2001 this percentage had increased to over 40 percent.

As for specific policy concerns, there are often marked differences between the positions of Democratic and Republican activists on controversial issues of the day. On the 14 issues posed in the survey, the percentage indicating agreement varies substantially between the parties on all but two questions. Activists from both parties overwhelmingly agree that women should have an equal role in business, industry, and government and that prayer should be allowed in public schools, although Democrats were somewhat less in agreement on this latter issue. But on many other important issues related to the economic and regulatory control of government, civil rights, and social policy, huge differences between Republicans and Democrats were observed. Take the first issue listed in Table 4 where activists were asked to agree or disagree with the following statement: "The government in Washington should provide fewer services, even in areas such as health and education, in order to reduce government spending." Less than 
Table 4. Ideology and Issue Position of Louisiana Party Activists

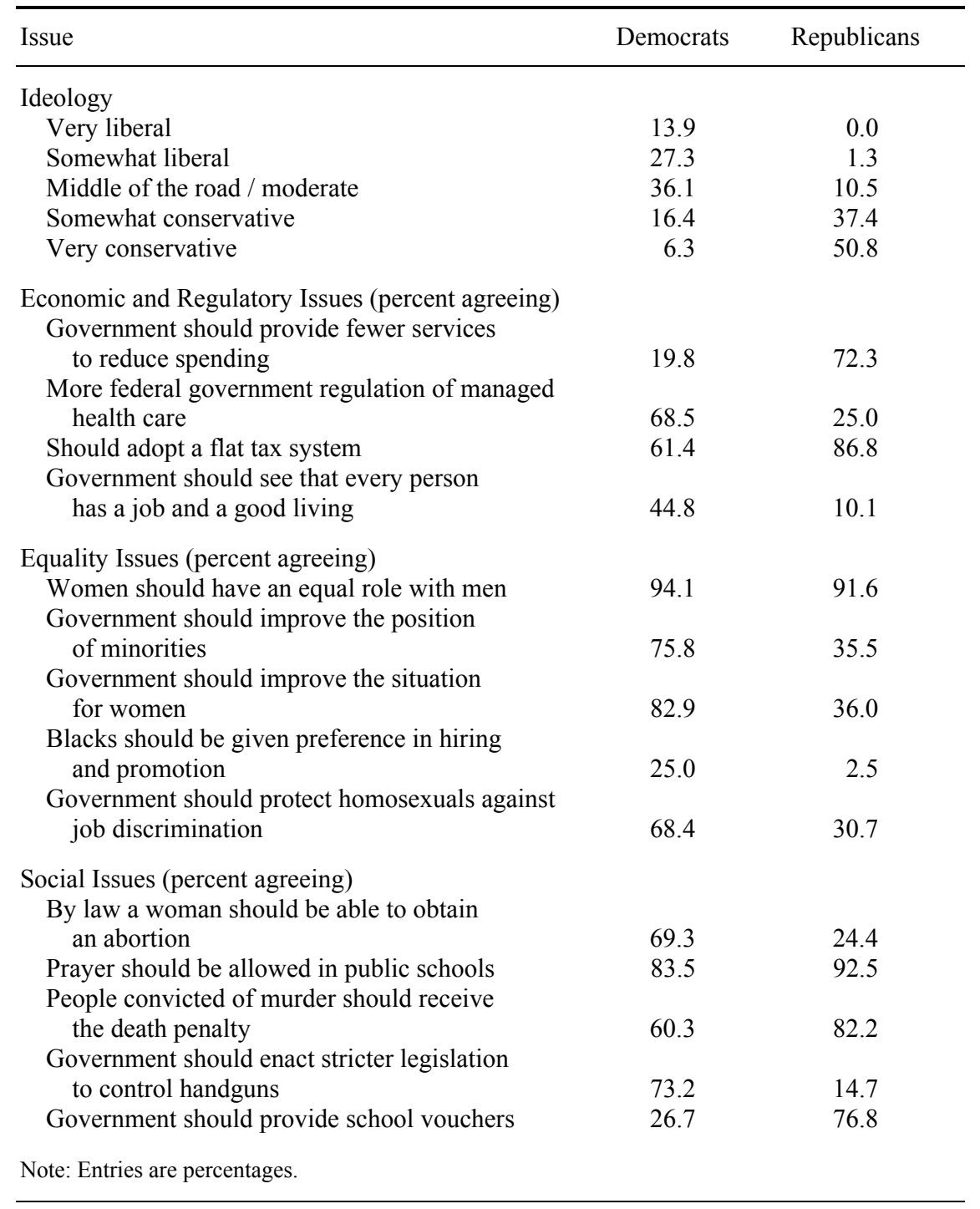

20 percent of Democratic activists agreed with that statement, while more than 73 percent of Republicans did. Another example of large inter-party differences was with the following statement: "There should be laws to protect homosexuals against job discrimination." Over 68 percent of Democrats agreed, while only about 31 percent of Republicans agreed. Finally, 
look at the differences on this issue: "The government should enact stricter legislation to control handguns." Nearly three-fourths of Democrats were in agreement (73 percent) but only about 15 percent of Republicans were. Overall, these examples illustrate the large differences that often separate the parties on matters of important public policy concerns.

Closely related to ideology and policy support is partisanship. Activists were asked to report their party affiliation on the national and state levels. Table 5 shows, as one might expect, that a majority of Democrats and Republicans identify with their own party on both these levels. But given the traditional conservative politics of southern Democrats, it is not surprising to find Democrats less supportive of their national party than Republicans. For example, 82 percent of Democrats and 85 percent of Republicans say they are "strong" members of their party on the state level. However, Democrats are clearly less supportive of their party on the national level than Republicans. While almost 90 percent of Republicans identify themselves as "strong" Republicans at the national level, only 72 percent of Democrats say they are "strong" Democrats in national politics. While this 72 percent figure for Democrats may seem low, this figure is certainly higher than the 57 percent found among party activists 10 years ago.

Another way to gauge support for the parties among activists is to ask how close or distant they feel to their party. Results in Table 5 show that compared to Republicans, Democrats are generally less supportive of their party on the state and national levels. Whereas 44 percent of Democrats say they feel close to their national party, about 69 percent of Republicans say they feel close to their party on the national level. Even on attitudes toward state party organizations, Democrats are less supportive than their Republican counterparts. But as with the affiliation question discussed earlier, Democrat sentiment has changed over time. While only 29 percent of Democrats said they felt close to their national party in 1991, ten years later that percentage had increased to over 44 percent. In combination, this evidence suggests that Democrats are less supportive of their national and state parties than Republicans, but over time there has been movement toward greater support.

To what extent are these attitudes towards parties manifested in the voting behavior of party activists? Might such differences in affinity toward the parties, particularly on the national level, affect how the activists cast their ballots? The bottom part of Table 5 shows the reported voting in three of the last four presidential elections. Republicans were much more supportive of their party's nominee than Democrats were of theirs in all three elections. Republicans overwhelmingly supported George H.W. Bush and George W. Bush by margins of 97 percent or better. Republicans defected more in 1996, but still over 90 percent supported Bob Dole for President. 
Table 5. Attitudes Toward and Support for Parties by Louisiana Activists

\begin{tabular}{lcc}
\hline & Democrats & Republicans \\
\hline Self-Described Party Affiliation in State Politics & & \\
Strong Democrat & 82.1 & 0.8 \\
Weak or Independent Democrat & 14.3 & 0.0 \\
Independent & 2.0 & 0.4 \\
Weak or Independent Republican & 0.4 & 13.5 \\
Strong Republican & 1.2 & 85.2 \\
Self-Described Party Affiliation in National Politics & & \\
Strong Democrat & 72.0 & 0.4 \\
Weak or Independent Democrat & 17.6 & 0.0 \\
Independent & 3.2 & 0.8 \\
Weak or Independent Republican & 4.4 & 9.1 \\
Strong Republican & 2.8 & 89.6 \\
Extent to which you feel CLOSE to the following parties & & \\
National Democratic Party & 44.2 & 2.1 \\
National Republican Party & 11.5 & 68.6 \\
State Democratic Party & 55.0 & 3.4 \\
State Republican Party & 7.5 & 67.8 \\
Voted for Party's Presidential Nominee & & \\
1988 & & \\
1996 & & \\
2000 & 65.1 & 97.4 \\
Ever Voted for Minor Party or Independent & 84.9 & 91.3 \\
Note: Entries are percentages. & 80.6 & 97.5 \\
\hline
\end{tabular}

Democrats on the other hand, supported their party's standard-bearer only 65 percent of the time in 1988, but this increased to approximately 85 percent in 1996. By 2000, however, support by Democrats slipped to about 81 percent. Thus, support among Democrats for their presidential nominee has increased, but it has not nearly reached the level seen among Republican activists.

Collectively this look at ideology, issue positions, and partisanship points to an increasing divide between Republican and Democratic Party activists. Over the last decade, the differences between the party activists on these fundamental attitudes have become more pronounced and have begun to mirror the divisions observed between the parties in national politics. 


\section{Integration and Factionalism of the Parties}

Two key characteristics that may help us better understand the role of political parties in the political system involves their level of integration and the degree of factionalism present within their organizations. Organizations that have a high degree of integration among their many parts and those that experience lower levels of factionalism are probably more efficient and effective organizations.

One way to measure the extent of integration of the party's many segments is to examine how often activists in the party communicate with one another. Parties where communication occurs frequently are probably more highly integrated organizations. Table 6 shows that communication occurs quite frequently among the activists within the parish committees and with local and state officials. For example, 62 percent of Democrats and nearly 69 percent of Republicans communicate "often" or "very often" with the parish executive committee chair. There is much less communication with the state party, and hardly any at all with the national party. For the most part, it appears that communication is higher for Republicans than for Democrats. For example, only 29 percent of Democrats report communicating often with the state party chair whereas 46 percent of Republicans report such a level of contact. Compared to levels observed a decade ago, we find that communication has increased among activists in both parties, but more so among Republicans. For example, while only 38 percent of Republicans in 1991 communicated "often" or "very often" with state government officials, by 2001 about 54 percent did so.

Given higher levels of communication over time in both parties, how might this affect the relationship among each party's following? Do higher levels of familiarity breed fondness or contempt? Upon which issues or dimensions do such divisions fall? Given the greater heterogeneity of Democratic activists and because they are seldom in lock step with their state and national organizations, we might expect to find a higher degree of disagreement among Democrats. But then again, given the acrimony observed of Republicans in Louisiana over the past decade, Republicans may report similar or even higher levels of disagreement within their party.

Respondents were asked about levels of disagreement within the party on a variety of different issues. Table 6 displays the percentage of activists who reported a "great deal of disagreement" on various dimensions. As one can see, on all but one of the 9 dimensions examined, a higher proportion of Democrats than Republicans indicated there was a great deal of disagreement within the party. On issues of taxes and race in particular, Democrats report much higher levels of disagreement than their Republican counterparts. It is instructive to note that the only instance in which disagreement is 


\section{Table 6. Communication and Factionalism within Louisiana Political Parties}

\begin{tabular}{|c|c|c|}
\hline & Democrats & Republicans \\
\hline \multicolumn{3}{|c|}{$\begin{array}{l}\text { How often do you communicate with the following members } \\
\text { of your party (very often and often indicated) }\end{array}$} \\
\hline County party chair (member responses only) & 62.0 & 68.8 \\
\hline Other county party committee members & 56.9 & 70.9 \\
\hline State party chair & 20.3 & 19.4 \\
\hline State party committee members & 29.2 & 46.3 \\
\hline National committee members & 6.9 & 18.0 \\
\hline Local government officials & 81.9 & 75.8 \\
\hline State government officials & 56.7 & 53.9 \\
\hline National government officials & 17.9 & 22.5 \\
\hline \multicolumn{3}{|l|}{$\begin{array}{l}\text { What level of disagreement is there within your party on } \\
\text { the following issues (great deal of disagreement indicated) }\end{array}$} \\
\hline Between people of different ideological viewpoints & 14.0 & 16.5 \\
\hline Between supporters of different party leaders & 24.3 & 21.3 \\
\hline Between life-long residents and newcomers & 15.9 & 6.9 \\
\hline Between different regions of the state & 31.1 & 17.9 \\
\hline Between urban and rural areas of the state & 31.8 & 23.0 \\
\hline On the issues of taxes & 25.7 & 11.0 \\
\hline On the issue of abortion & 32.5 & 27.2 \\
\hline On racial issues & 29.8 & 15.1 \\
\hline On issues of government spending & 26.1 & 17.3 \\
\hline \multicolumn{3}{|l|}{ What is the level of factionalism in your state party? } \\
\hline Very high & 10.8 & 10.7 \\
\hline Moderately high & 54.2 & 56.2 \\
\hline Moderately low & 32.5 & 28.3 \\
\hline Very low & 2.5 & 4.7 \\
\hline \multicolumn{3}{|l|}{ What is the level of factionalism in your county party? } \\
\hline Very high & 13.9 & 6.9 \\
\hline Moderately high & 42.0 & 25.1 \\
\hline Moderately low & 32.4 & 35.1 \\
\hline Very low & 11.8 & 28.5 \\
\hline
\end{tabular}

higher for Republicans than for Democrats is for differences in ideological viewpoints, something that corroborates the earlier discussion concerning organizational difficulties within the Republican Party since the 1980s.

Another way to gauge the level of disagreement is to ask specifically about the extent of factionalism within the party on the state and local levels. Activists from both parties report similar levels of factionalism within their 
state organization. Slightly less than 11 percent in both parties say factionalism is "very high" while 54 percent of Democrats and 56 percent of Republicans report factionalism to be "moderately high." On the local level, respondents from both parties report lower levels of factionalism, but Democrats report higher levels than do Republicans.

These results show that the disagreements and factionalism are present in both parties, although they are more frequent within the Democratic Party. Given the heterogeneous makeup of the Democrats, such differences are not altogether surprising.

\section{Organizational Activity}

What types of activities do party organizations engage in during elections? Table 7 indicates the percentage of executive committee members who report various activities. In the first category of recruitment, large percentages in each party say that they talk with candidates about running or suggest to someone that they should think about running for office. More than 70 percent of activists from both parties say they have talked to candidates prior to their official announcement. Over 80 percent in both parties responded affirmatively to the more general question of whether they have suggested that someone run for office. These percentages are similar those uncovered a decade ago, although Democrat recruitment activity appears to diminish slightly over the time period.

What about other activities related to political campaigns? Distributing literature and posters along with contributing money were common activities mentioned by activists in both parties. Conversely, purchase of billboard space and utilizing public opinion surveys were reported much less often. Overall, the activity levels of the two parties are similar. The only large differences are that Democrats are more likely to engage in door-to-door canvassing and telephone campaigns while Republican are more likely to send literature through the mail, distribute signs, and contribute money. Over the last decade, activity levels remained rather constant for Republicans, while Democratic activity levels increased in 9 of 12 areas where direct comparisons can be made.

A final measure of organizational activity of the parties is obtained by asking activists about their general level of activity on the local, state and national levels. Members of both parties report higher levels of activity at the local level than at the state or national levels. In terms of differences between parties, we find that Democrats report more activity on the local level while Republicans are more active in national-level politics. Over time changes have occurred mostly among Democratic activists. Whereas in 1991 only 26 percent of activists said they were very active in national politics, by 
Table 7. Activities of Louisiana Party Officials in Recent Election Campaigns

\begin{tabular}{lcc}
\hline & Democrats & Republicans \\
\hline $\begin{array}{l}\text { Recruitment } \\
\text { Have candidates ever talked with you about running }\end{array}$ & & \\
$\quad$ for office before they announced their candidacy? & 72.8 & 74.2 \\
$\quad$ Have you ever suggested to someone that they & & \\
$\quad$ ought to run for public office? & 84.0 & 83.3 \\
Campaign Activities & & \\
Organized door-to-door canvassing & 50.2 & 38.9 \\
Organized campaign events & 43.6 & 47.5 \\
Arranged fund-raising activities & 36.2 & 40.2 \\
Sent mailings to voters & 40.1 & 47.5 \\
Distributed campaign literature & 68.5 & 68.4 \\
Organized telephone campaigns & 45.5 & 37.7 \\
Purchased billboard space & 8.9 & 6.6 \\
Distributed posters or lawn signs & 71.2 & 80.3 \\
Contributed money to campaigns & 61.9 & 74.2 \\
Conducted voter registration drives & 33.1 & 30.7 \\
Utilized public opinion surveys & 18.3 & 14.8 \\
Dealt with campaign media & 30.0 & 28.3 \\
Helped to construct or maintain a campaign website & 2.7 & 9.8 \\
Level of Activity & & \\
How active are you generally in (percent indicating VERY active) & \\
$\quad$ Local & 74.6 & 57.9 \\
$\quad$ State & 43.1 & 45.7 \\
$\quad$ National & 40.7 & 50.2 \\
Note: Entries are percentages. & & \\
\hline
\end{tabular}

2001 this percentage had increased to over 40 percent. Such changes in party activities are reflective of the movement in Democrats' attitudes toward their national parties.

\section{Conclusions}

Party politics in Louisiana remains in a period of transition. Republican gains have been significant, but their successes have not been pervasive. Findings from this analysis of party activists suggest that both major parties are still changing in many ways, although the greatest changes have occurred within the Democratic Party. The demographic makeup of the party has been altered, especially as African Americans have come to comprise a 
larger percentage of the membership. Accompanying this change has been a growing willingness on the part of Democratic activists to identify themselves as "liberal," to give greater support to their national party, and to vote for their party's presidential nominee.

The growing distinctiveness of the two parties may have consequences for the activities undertaken by the party organizations and for the electorate's voting behavior in coming years. More polarized parties in Louisiana may energize the party faithful in a manner not seen in the past. Distinctive policy alternatives provided by parties might also make the choices of voters clearer at election time. Only time will tell if such systemic changes will come to pass.

\section{REFERENCES}

Hadley, Charles D., and Jennifer E. Horan. 1995. Louisiana: Two-Party Conservatism. In Southern State Party Organizations and Activists, eds. Charles D. Hadley and Lewis Bowman. Westport, CT: Praeger.

Kuzenski, John C., Charles S. Bullock and Ronald Keith Gaddie. 1995. David Duke and the Politics of Race in the South. Nashville, TN: Vanderbilt University Press.

Parent, T. Wayne. 1997. Louisiana. In State Party Profiles: A 50-State Guide to Development, Organization, and Resources, eds. Andrew Appleton and Daniel S. Ward. Washington, DC: Congressional Quarterly Press.

Parent, T. Wayne, and Huey Perry. 1998. Louisiana: African Americans, Republicans, and Party Competition. In The New Politics of the Old South: An Introduction to Southern Politics, eds. Charles S. Bullock, III and Mark J. Rozell. Lanham: Rowman and Littlefield.

Renwick, Edward F., T. Wayne Parent, and Jack Wardlaw. 1999. Louisiana: Still Sui Generis Like Huey. In Southern Politics in the 1990s, ed. Alexander Lamis. Baton Rouge: Louisiana State University Press.

Rose, Douglas. 1992. The Emergence of David Duke and the Politics of Race. Chapel Hill: University of North Carolina Press. 